\title{
Luminescent Ruthenium(II) Polypyridyl Functionalized Gold Nanoparticles; Their DNA Binding Abilities and Application As Cellular Imaging Agents
}

Robert B. P. Elmes, ${ }^{+, \S}$ Kim N. Orange, ${ }^{\neq, \S}$ Suzanne M. Cloonan, ${ }^{\neq, \S}$ D. Clive Williams, ${ }^{*, \neq, \S}$ and Thorfinnur Gunnlaugsson ${ }^{*,+}$,

+ School of Chemistry, Centre for Synthesis and Chemical Biology, Trinity College, Dublin, Dublin 2, Ireland

${ }^{\ddagger}$ School of Biochemistry and Immunology, Trinity College, Dublin 2, Ireland

$\S_{\text {Trinity College Biomedical Sciences Institute, Dublin 2, Ireland }}$

Supporting Information

ABSTRACT: The synthesis and photophysical and biological investigation of $\mathrm{Ru}(\mathrm{II})$-polypyridyl stabilized watersoluble, luminescent gold nanoparticles (AuNPs) are described. These structures bind to DNA and undergo rapid cellular uptake, being localized within the cell cytoplasm and nucleus within $4 \mathrm{~h}$.

$\mathrm{T}$ he development of functional supramolecular nanostructures for applications in photonics, ${ }^{1}$ sensing, ${ }^{2}$ catalysis $^{3}$ and medicine, ${ }^{4}$ etc. is a fast emerging interdisciplinary research field. The design and synthesis of nanoparticles ${ }^{5}$ and, in particular, functionalized gold nanoparticles (AuNPs) has been at the forefront of this effort in recent times, with many examples being developed for use in biological and medical applications, ${ }^{6}$ due to their biocompatibility, unique size- and shape-dependence, and optoelectronic properties. Similarly, $\mathrm{Ru}(\mathrm{II})$-polypyridyl complexes have been intensively studied due to their photophysical properties, $^{7}$ where they have been employed for example in luminescent recognition and sensing, ${ }^{8}$ as sensitive and structurespecific DNA probes. ${ }^{9}$ Luminescent $\mathrm{d}^{6}$ transition metal ion complexes have often been proposed as useful fluorophores for cellular imaging, ${ }^{10,11}$ but until very recently their use in actual applications has remained scarce. With our interest in the development of luminescent novel cellular targeting (therapeutic/ imaging) agents ${ }^{7 \mathrm{a}, \mathrm{b}, 12}$ and surface modified AuNPs, ${ }^{13}$ we envisaged that the combination of $\mathrm{Ru}(\mathrm{II})$-polypyridyl complexes, spatially separated from the surface of AuNPs, by a covalent spacer, could be employed as luminescent probes/imaging agents for various biological applications. ${ }^{15}$ Herein we describe the synthesis of the $\mathrm{Ru}(\mathrm{II})$ complexes $1-3$, Figure 1, all of which possess a terminal alkyl thiol group which facilitates their adsorption onto AuNPs, leading to the formation of the three water-soluble systems AuNP1, AuNP-2 and AuNP-3 (Figure 1). We demonstrate that these luminescent AuNPs offer attractive photophysical properties, ideal for application in cellular imaging, which we demonstrate using HeLa cells. These are, to the best of our knowledge, the first examples of such $\mathrm{Ru}$ (II)-polypyridyl functionalized AuNPs to be employed for such cellular applications.

The syntheses of $\mathbf{1}, \mathbf{2}$, and $\mathbf{3}$ are shown in Scheme S1 (see also full details in Supporting Information) and were achieved in a few steps. The common ligand for all of these complexes is 4 ,

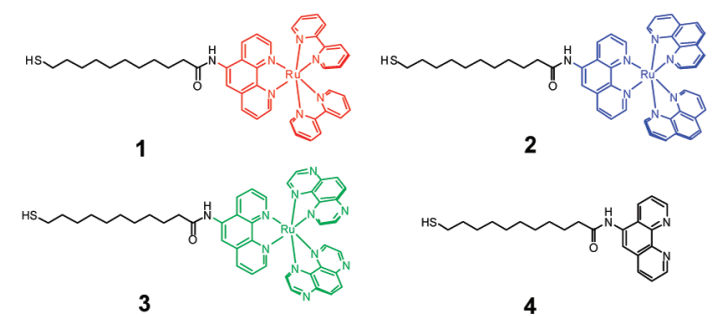

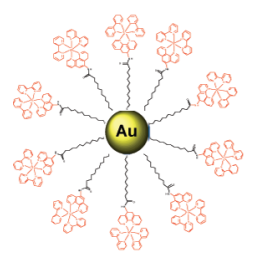

AuNP-1

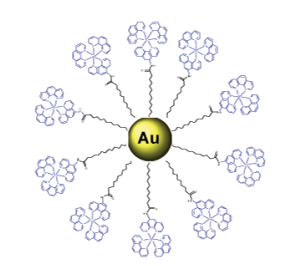

AuNP-2

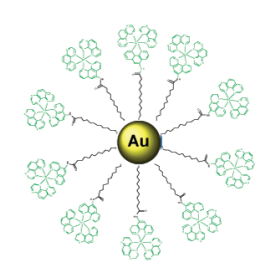

AuNP-3
Figure 1. Structure of the complexes 1, 2, and $3(R u=R u(I I))$, ligand 4, and cartoon representation of their corresponding AuNPs-1-3 systems.

the synthesis of which was achieved by employing peptidic (carbodiimide) coupling of 11-mercaptoundecanoic acid ${ }^{14 a}$ with 5-amino,-1,10 phenanthroline in $\mathrm{CH}_{2} \mathrm{Cl}_{2}$, yielding 4 as an offwhite solid in $78 \%$ yield. The microwave irradiation of 4 in the presence of the $\mathrm{Ru}$ (II) bispolypyridyl dichlorides $\mathrm{Ru}(\text { bpy })_{2} \mathrm{Cl}_{2}$, $\mathrm{Ru}$ (phen $)_{2} \mathrm{Cl}_{2}$, and $\mathrm{Ru}(\mathrm{TAP})_{2} \mathrm{Cl}_{2}$ gave 1,2 , and 3 , respectively, after $40 \mathrm{~min} .{ }^{14 \mathrm{~b}}$ These were isolated, by precipitation from water, using excess $\mathrm{NH}_{4} \mathrm{PF}_{6}$, followed by purification using automatic column chromatography [flash silica; 40:4:1 $\mathrm{CH}_{3} \mathrm{CN} / \mathrm{H}_{2} \mathrm{O}$ / $\mathrm{NaNO}_{3}$ (sat)], yielding $\mathbf{1}-3$ in $75 \%, 65 \%$, and 54\%, respectively. These isolated $\mathrm{NO}_{3}{ }^{-}$salts were reconverted to their corresponding $\mathrm{PF}_{6}{ }^{-}$salts and were fully characterized, which included the use of $1 \mathrm{D}$ and 2D NMR. The characteristic MLCT based absorbance spectra of $1-3$, together with the excitation and emission spectra, are shown in the Supporting Information. All of the complexes were found to be fully water-soluble as their $\mathrm{Cl}^{-}$ salts (see Supporting Information), and their photophysical properties were investigated in $10 \mathrm{mM}$ phosphate-buffered aqueous solutions at $\mathrm{pH}$ 7.4. The absorption spectrum of $\mathbf{1}$ showed characteristic $\pi-\pi^{*}$ intraligand transitions centered at

Received: July 1, 2011

Published: September 16, 2011 


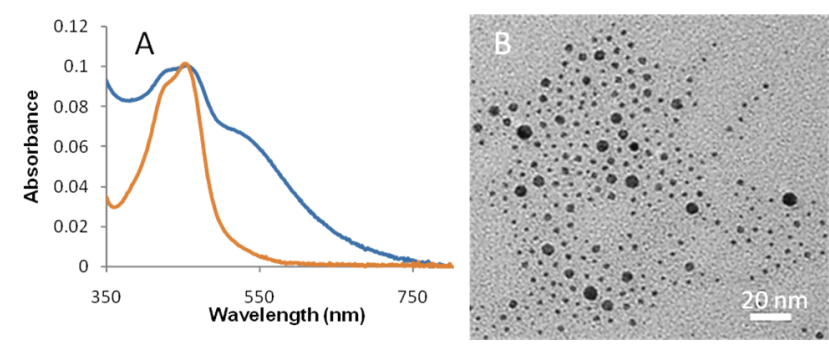

Figure 2. (A) MLCT absorption band of $\mathbf{1}$, and AuNP-1 in buffered $\mathrm{H}_{2} \mathrm{O}$ at $\mathrm{pH}$ 7.4. (B) Transmission electron microscopy image of AuNP-1.

$285 \mathrm{~nm}\left(\varepsilon=49500 \mathrm{~cm}^{-1} \mathrm{M}^{-1}\right)$ assigned to the ancillary ligands, while the characteristic MLCT transitions of the $\mathrm{Ru}(\mathrm{II})$ center were observed at $450 \mathrm{~nm}\left(\varepsilon=12400 \mathrm{~cm}^{-1} \mathrm{M}^{-1}\right)$. Similar transitions were found for $\mathbf{2}$ and $\mathbf{3}$. Excitation into the MLCT bands of 1-3 gave rise to, on all occasions, MLCT based emission occurring at $\lambda_{\max }=610 \mathrm{~nm}\left(\Phi_{\mathrm{F}}=0.054\right), 605 \mathrm{~nm}$ $\left(\Phi_{\mathrm{F}}=0.056\right)$, and $635 \mathrm{~nm}\left(\Phi_{\mathrm{F}}=0.028\right)$, for $1-3$, respectively. For all of these, the excitation spectra structurally matched those of the absorption spectra.

The syntheses of AuNP-1-3 were achieved using the twophase Brust method which gave tetraoctylammoniumbromide (TOAB) stabilized AuNPs. ${ }^{15 a}$ Exchange of TOAB on the surface of AuNPs with 1-3 was achieved upon stirring TOAB-AuNP with $1-3$, respectively, for $12 \mathrm{~h}$ at room temperature, followed by centrifugation and the removal of any unbound complex by employing a method developed by Mayer et al. ${ }^{15 \mathrm{~b}}$ involving double anion exchange. The AuNPs were characterized using UV-visible spectroscopy, where the surface plasmon resonance (SPR) band was found at $520 \mathrm{~nm}$ (Supporting Information) slightly overlapping with the MLCT absorption bands of $\mathbf{1 - 3}$, Figure 2A. Using UV-vis spectroscopy, AuNP-1-3 were found to be stable in aqueous-buffered solution at $\mathrm{pH} 7.4$ at room temperature for many months. Excitation into the MLCT absorption bands of AuNP-1-3 gave rise to, on all occasions, MLCT centered emission with $\lambda_{\max }$ at 610,605 , and $635 \mathrm{~nm}$, for AuNP-1 -3 respectively, with $\phi_{\mathrm{F}}$ of $\sim 0.002$, demonstrating that these were significantly less emissive after adsorption to the AuNP surface, as has previously by seen for $\left[\mathrm{Ru}(\mathrm{bpy})_{3}\right]^{2+}$ in the presence of AuNPs coated with thiolate monolayers. ${ }^{15 c}$ AuNP1-3 were further characterized using TEM, which showed spherical nanoparticles with an average diameter of $4.0 \pm 1.3$, $4.3 \pm 1.3$, and $3.2 \pm 1.1 \mathrm{~nm}$ for AuNP-1, AuNP-2, and AuNP-3 respectively, with no evidence of aggregation, Figure $2 \mathrm{~A}$, and using DLS which gave hydrodynamic radii of 3-7 nm (Supporting Information).

$\mathrm{Ru}$ (II)-polypyridyl complexes are known to bind to DNA and cause photosensitized DNA damage, but the binding constant and the photocleavage efficiency are highly structurally dependent. ${ }^{7,16}$ Consequently, the DNA binding affinities of $\mathbf{1}-\mathbf{3}$, and AuNP-1-3, were evaluated in $10 \mathrm{mM}$ phosphate buffer at $\mathrm{pH} 7.4$ using salmon testes DNA. In the case of 1-3, DNA binding gave rise to hypochromic effects in the MLCT band in the UV-vis absorption spectra, which in the case of 1 was ca. $30 \%$ (Supporting Information). From these, a binding constant $K_{\mathrm{b}}=5.5 \times 10^{5} \mathrm{M}^{-1}$ was determined, while, for $3, K_{\mathrm{b}}=6.4 \times 10^{5}$ $\mathrm{M}^{-1}$ was calculated. Concomitantly, the MLCT centered emission was also modulated, being most noticeable for 3 , with ca. $75 \%$ quenching being observed (see Supporting Information). Similarly, the binding of AuNP-1 -3 also gave rise to changes in

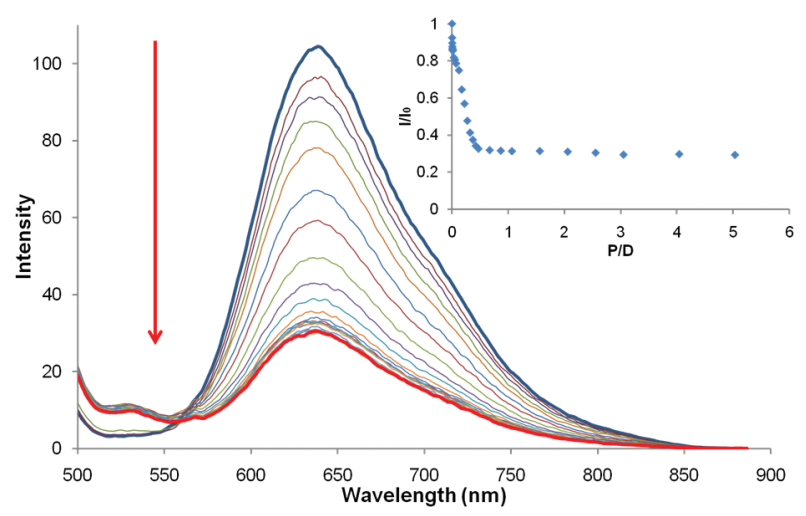

Figure 3. Changes in the emission spectrum of AuNP-3 $\left(\lambda_{\text {ex }} 450 \mathrm{~nm}\right)$ with increasing concentration of DNA $(0-77 \mu \mathrm{M})$. The blue and the red spectra demonstrated the non-DNA and the DNA bound AuNP-3. Inset: Plot of the change in integrated MLCT intensity as a function of $\mathrm{P} / \mathrm{D}$ ratio.

the photophysical properties of the surface modified $\mathrm{Ru}(\mathrm{II})$ complexes. In the case of AuNP-1, an initial red shift in the UV-vis absorption spectra, followed by a ca. $26 \%$ hypochroism, was observed upon binding to DNA. Similar changes were seen for AuNP-2 and AuNP-3. Significant changes were also seen in the emission spectra of AuNP-1-3, as demonstrated in Figure 3, upon binding of AuNP-3 to DNA, giving rise to $71 \%$ quenching in the MLCT based emission (see Supporting Information for AuNP-1-2). This is in agreement with the behavior of other $\pi$-deficient $\mathrm{Ru}(\mathrm{II})$ complexes of the general formula $[\mathrm{Ru}$ $\left.(\mathrm{TAP})_{2}(\mathrm{~L})\right]^{2+}(\mathrm{L}=$ phen or bpy $){ }^{16}$ as those complexes containing two TAP ligands have been shown to photo-oxidize guaninecontaining nucleotides through a proton coupled photoinduced electron transfer (PCET) process. ${ }^{17}$ The affinities of AuNP-1 - 3 for DNA were further confirmed by carrying out ethidium bromide (EtBr) displacement assays (Supporting Information), ${ }^{18}$ which demonstrated that AuNP-1-3 displaced EtBr with an apparent binding constant $\left(K_{\text {app }}\right)$ of $\sim 10^{7} \mathrm{M}^{-1}$. From these results, it is clear that AuNP-1-3 all interact with DNA in a strong manner. To further confirm this, we investigated the ability of these nanostructures to bind to DNA using confocal fluorescence imaging, by treating a solution of DNA $(4 \mathrm{mM})$ with a solution of AuNP-1-3. This led to immediate formation of a precipitate and the formation of fibrous networks and smaller aggregates, which are currently under investigation in our laboratory.

Having demonstrated high DNA binding affinities of AuNP1-3, we next carried out cellular uptake and localization studies of these systems using confocal fluorescence microscopy. We anticipated that AuNP-1-3 would be taken up by cells as has been seen with many AuNP conjugates. ${ }^{19}$ This may occur through receptor mediated transport (e.g., endocytosis), or by plasma membrane driven transport due to their cationic nature. The results are shown in Figure 4. In Figure 4A, a brighfield image shows the presence of the AuNP (as aggregates) within live HeLa (cervical cancer) cells as dense 'dark spots', after incubation with AuNP-1 $(\sim 16 \mathrm{nM}) 4 \mathrm{~h}$ prior to imaging. Fluorescence confocal laser scanning microscopy confirmed this uptake and localization, as demonstrated in Figure 4B, which shows an image of these cells upon excitation at $450 \mathrm{~nm}$, where these dense areas of Figure 4A are seen to overlap perfectly with 

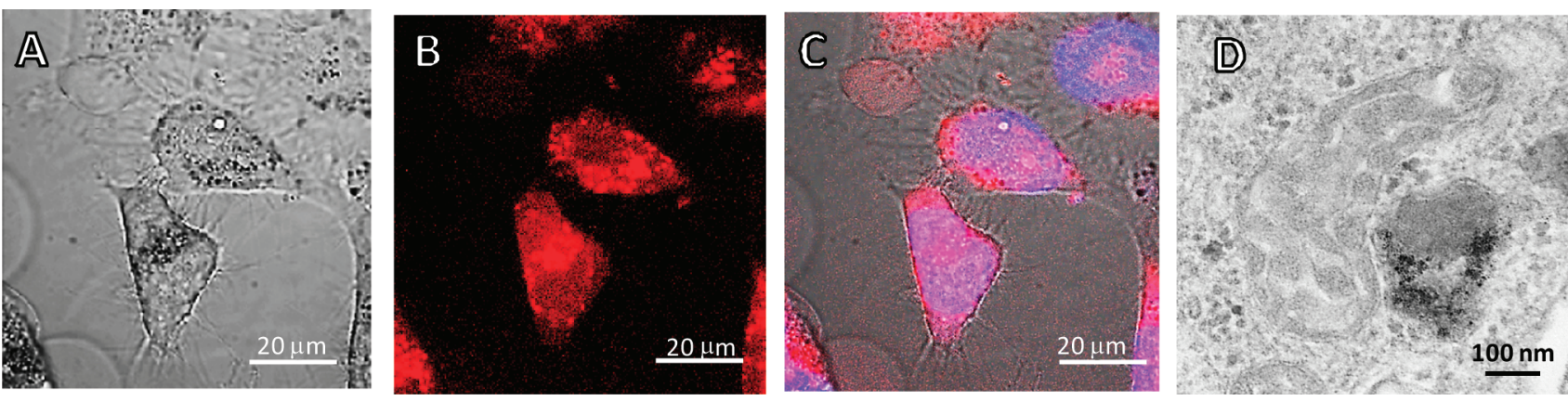

Figure 4. Live cell confocal laser scanning microscopy images of AuNP-1 $\left(\sim 16 \mathrm{nM}\right.$ gold concentration $\left.{ }^{20}\right)$ with HeLa cells: (A) the bright field image; (B) emission arising from 600 to $700 \mathrm{~nm}$; (C) overlay of the luminescence from AuNP-1 (red), nuclear costain DAPI (blue), and the bright field image; (D) TEM image of AuNP-1 following incubation with HeLa cells.
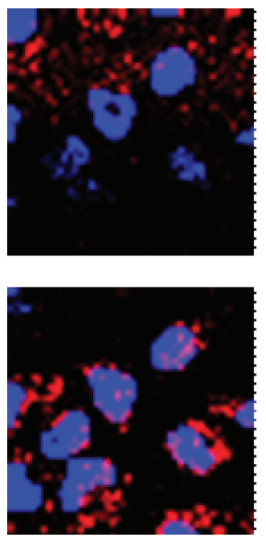
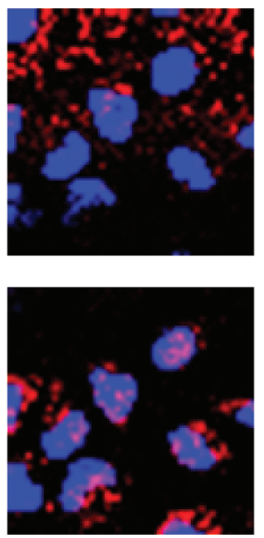
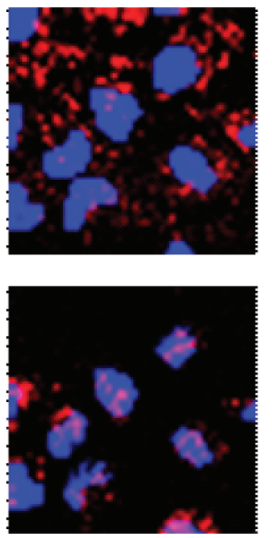
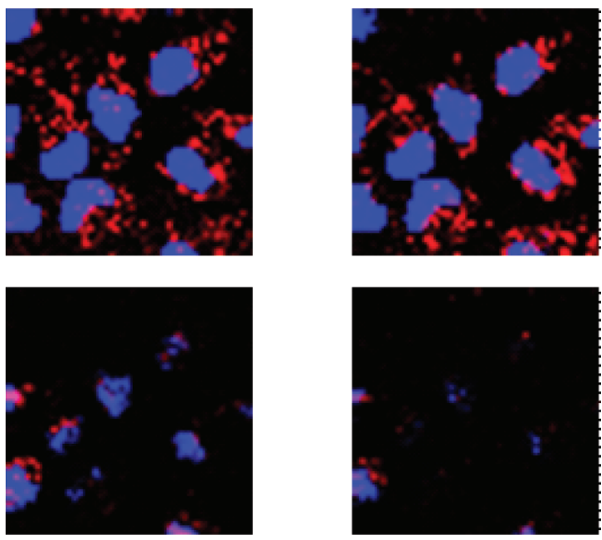

Figure 5. Confocal fluorescence Z-section live cell images of AuNP-2 $(20 \mu \mathrm{M})$ with Hela cells showing luminescence in three dimensions. Shown is the image obtained with cells costained with nuclear stain DAPI (blue) and AuNP-2 (red). Scanning from left to right.

the red fluorescence emanating from within the cell interior. The image clearly confirms that AuNP-1 is luminescent within the cells; with apparent localization in the cytoplasm and the nucleus, where these can be seen as discrete 'packets' or aggregates of fluorescence. In addition, Z-stack experiments clearly show that the observed luminescence is spherical in three dimensions; corresponding to the AuNPs being located inside the cells and not bound to their exterior, Figure 5, for AuNP-2 (See larger image in Supporting Information as well as for AuNP-1 and AuNP-3).

Costaining of the nucleus, using DAPI, further confirmed the nuclear localization of AuNP-1, as demonstrated in Figure 4C, where the costained image is overlapped with the bright field image (Figure 4A) and the luminescent image (Figure 4B). Similar behavior was observed for AuNP-2, Figure 5, and AuNP3 with the luminescence intensity being slightly diminished in the case of AuNP-3 due to the PCET process discussed above (Supporting Information). The uptake of AuNP-1 was also confirmed by TEM imaging within the HeLa cells, confirming their localization within both the cytosol, Figure 4D, and the nucleus. We also carried out time dependent fluorescence confocal imaging studies, where the cellular uptake of AuNP-1 was imaged at 2 and $6 \mathrm{~h}$ in addition to the $4 \mathrm{~h}$ discussed above. The results (see Supporting Information) clearly demonstrated that only minimal uptake had occurred after $2 \mathrm{~h}$. After $6 \mathrm{~h}$, results similar to those seen at $4 \mathrm{~h}$ were observed, though with slightly enhanced cellular contrast.
To assess the antiproliferative effects of these AuNPs we attempted to determine the $\mathrm{EC}_{50}$ value of AuNP-1 by carrying out an Alamar blue cytotoxicity assay with a large range of concentrations of AuNP-1 in the mesothelioma cell line CRL5195. In short, and as is evident from Figures 4 and 5 using HeLa cells, no significant apoptosis was observed for AuNP-1, and in fact, an $\mathrm{IC}_{50}$ value could not be determined for AuNP-1 from the concentration range used as $\%$ viability did not drop below $60 \%$ (see Supporting Information).

In summary, we have developed, to the best of our knowledge, the first examples of novel supramolecular DNA targeting motifs based on $\mathrm{Ru}$ (II) stabilized AuNPs. We have shown that AuNP1-3 all bind to DNA with high affinity, while at the same time being nontoxic, and that we can monitor the binding of these to DNA using various spectroscopic techniques. Moreover, by using fluorescence confocal microscopy and TEM imaging studies, we have demonstrated their cellular uptake and localization within the cytoplasm and nucleus. These studies confirm the potential use of such $\mathrm{Ru}(\mathrm{II})$ polypyridyl functionalized AuNPs as highly sensitive cellular imaging agents. We are currently investigating the mechanism of their uptake, and their fate, in greater detail.

\section{ASSOCIATED CONTENT}

Supporting Information. Synthesis and characterization of 1, 2, and 3; Figures $S 1-S 30$. This material is available free of charge via the Internet at http://pubs.acs.org. 


\section{AUTHOR INFORMATION}

\section{Corresponding Author}

clive.williams@tcd.ie; gunnlaut@tcd.ie

\section{ACKNOWLEDGMENT}

We thank the Science Foundation Ireland (SFI RFP 2009), HEA PRTLI Cycle 4, The Irish Research Council for Science, Engineering and Technology (IRCSET Postgraduate Studentship to R.B.P.E.), and TCD for financial support

\section{REFERENCES}

(1) Ozbay, E. Science 2006, 311, 189.

(2) (a) Bunz, U. H. F.; Rotello, V. M. Angew. Chem., Int. Ed. 2010, 49, 3268. (b) Moloney, M. P.; Gun'ko, Y. K.; Kelly, J. M. Chem. Commun. 2007, 3900. (c) Labande, A.; Ruiz, J.; Astruc, D. J. Am. Chem. Soc. 2002, 124, 1782.

(3) Bell, A. T. Science 2003, 299, 1688.

(4) (a) Kim, C.; Agasti, S. S.; Zhu, Z.; Isaacs, L.; Rotello, V. M. Nat. Chem. 2010, 2, 962. (b) Rosi, N. L.; Mirkin, C. A. Chem. Rev. 2005, $105,1547$.

(5) (a) David, A. G.; Dwight, S. S.; Weston, L. D.; Matthew, D. M.; Pinal, C. P.; Chad, A. M. Angew. Chem., Int. Ed. 2010, 49, 3280. (b) Coskun, A.; Klajn, R.; Fang, L.; Olson, M. A.; Wesson, P. J.; Trabolsi, A.; Dey, S. K.; Grzybowski, B. A.; Stoddart, J. F. J. Am. Chem. Soc. 2010, 132, 4310. (c) Daniel, M.-C.; Astruc, D. Chem. Rev. 2003, 104, 293.

(6) (a) Saha, K.; Bajaj, A.; Duncan, B.; Rotello, V. M. Small 2011, 7, 1903. (b) Ghosh, P.; Gang, H.; Mrinmoy, D.; Chae Kyu, K.; Rotello, V. M. Adv. Drug Delivery Rev. 2008, 60, 1307. (c) Montalti, M.; Zaccheroni, N.; Prodi, L.; O’Reilly, N.; James, S. L. J. Am. Chem. Soc. 2007, 129 (9), 2418.

(7) (a) Nonat, A. M.; Quinn, S. J.; Gunnlaugsson, T. Inorg. Chem. 2009, 48, 4646. (b) Ryan, G. J.; Quinn, S.; Gunnlaugsson, T. Inorg. Chem. 2008, 47, 401. (c) Zeglis, B. M.; Pierre, V. C.; Barton, J. K. Chem. Commun. 2007, 4565. (d) Moucheron, C.; Kirsch De Mesmaeker, A.; Kelly, J. M. J. Photochem. Photobiol. B 1997, 40, 91. (e) Erkkila, K. E.; Odom, D. T.; Barton, J. K. Chem. Rev. 1999, 99, 2777. (f) Metcalfe, C.; Thomas, J. A. Chem. Soc. Rev. 2003, 32, 215. (g) Gill, M. R.; Garcia-Lara, J.; Foster, S. J.; Smythe, C.; Battaglia, G.; Thomas, J. A. Nat. Chem. 2009, 1, 662. (h) Vos, J. G.; Kelly, J. M. Dalton Trans. 2006, 4869.

(8) Elmes, R. B. P.; Gunnlaugsson, T. Tetrahedron Lett. 2010, $51,4082$.

(9) (a) Matson, M.; Svensson, F. R; Nordén, B.; Lincoln, P. J. Phys. Chem. B 2011, 115, 1706. (b) Puckett, C. A.; Barton, J. K. Biorg. Med. Chem. 2010, 18, 3564. (c) Tan, C. P.; Lai, S. S.; Wu, S. H.; Hu, S.; Zhou, L. J.; Chen, Y.; Wang, M. X.; Zhu, Y. P.; Lian, W.; Peng, W. L.; Ji, L. N.; Xu, A. L J. Med. Chem. 2010, 53, 7613. (d) Cosgrave, L.; Devocelle, M.; Forster, R. J.; Keyes, T. E. Chem. Commun 2010, 46, 103.

(10) (a) Zhao, Q.; Huang, C. H.; Li, F. Y. Chem. Soc. Rev. 2011, 40, 2508. (b) Fernandez-Moreira, V.; Thorp-Greenwood, F. L.; Coogan, M. P. Chem. Commun. 2010, 46, 186.

(11) (a) Gill, M. R.; Derrat, H.; Smythe, C. G. W.; Battaglia, G.; Thomas, J. A. ChemBioChem 2011, 12, 877. Tian, X.; Gill, M. R.; Cantón, I.; Thomas, J. A.; Battaglia, G. ChemBioChem 2011, 12, 548. (b) Puckett, C. A.; Ernst, R. J.; Barton, J. K. Dalton Trans. 2010, 39, 1159. (c) Puckett, C. A.; Barton, J. K. J. Am. Chem. Soc. 2009, 131, 8738. (d) Puckett, C. A.; Barton, J. K. Biochemistry 2008, 47, 11711.

(12) (a) Elmes, R. B. P.; Erby, M.; Cloonan, S. M.; Quinn, S. J.; Williams, D. C.; Gunnlaugsson, T. Chem. Commun. 2011, 47, 686. (b) Veale, E. B.; Gunnlaugsson, T. J. Org. Chem. 2010, 75, 5513. (c) Veale, E. B.; Frimannsson, D. O.; Lawler, M.; Gunnlaugsson, T. Org. Lett. 2009, 11,4040 .

(13) (a) Comby, S.; Gunnlaugsson T. ACS Nano 2011, 5, DOI: $10.1021 / \mathrm{nn} 201992 \mathrm{z}$. (b) Massue, J.; Quinn, S. J.; Gunnlaugsson, T. J. Am. Chem. Soc. 2008, 130, 6900. (c) Bonnet, C. S.; Massue, J.; Quinn, S. J.; Gunnlaugsson, T. Org. Biomol. Chem. 2009, 7, 3074.
(14) (a) Zhu, M.; Schneider, M.; Papastavrou, G.; Akari, S.; Mohwald, H. Langmuir. 2001, 17, 6471. (b) Rau, S.; Schäfer, B.; Grüßing, A.; Schebesta, S.; Lamm, K.; Vieth, J.; Görls, H.; Walther, D.; Rudolph, M.; Grummt, U. W.; Birkner, E. Inorg. Chim. Acta 2004, 357, 4496.

(15) (a) Brust, M.; Walker, M.; Bethell, D.; Schiffrin, D. J.; Whyman, R. J. Chem. Soc., Chem. Commun. 1994, 801. (b) Mayer, C. R.; Dumas, E.; Secheresse, F. J. Colloid Interface Sci. 2008, 328, 452. (c) Huang, T.; Murray, R. W. Langmuir 2002, 18, 7077.

(16) (a) Lecomte, J.-P.; Kirsch-De Mesmaeker, A.; Feeney, M. M.; Kelly, J. M. Inorg. Chem. 1995, 34, 6481. (b) Elias, B.; Creely, C.; Doorley, G. W.; Feeney, M. M.; Moucheron, C.; Kirsch-Demesmaeker, A.; Dyer, J.; Grills, D. C.; George, M. W.; Matousek, P.; Parker, A. W.; Towrie, M.; Kelly, J. M. Chem.-Eur. J. 2007, 14, 369.

(17) (a) Herman, L.; Ghosh, S.; Defranq, E.; Kirsch De Mesmaeker, A. J. Phys. Org. Chem. 2008, 21, 670. (b) Kelly, J. M.; McConnell, D. J.; O’ Huigin, C.; Tossi, A. B.; Kirsch De Mesmaeker, A.; Masschelein, A.; Nasielski, J. J. Chem. Soc., Chem. Commun. 1987, 1821.

(18) Boger, D. L.; Fink, B. E.; Brunette, S. R.; Tse, W. C.; Hedrick, M. P. J. Am. Chem. Soc. 2001, 123, 5878.

(19) Chithrani, B. D.; Chazani, A. A.; Chan, W. C. W. Nano Lett. 2006, 6, 662 .

(20) Tataon, T. A. Current Protocols in Nucleic Acid Chemistry; John Wiley \& Sons, Chester, UK, 2002; pp 12.1-12.2.12. 